\title{
Identifikasi Risiko Green Supply Chain Management di PT Petrokimia Gresik
}

\author{
Azari, S., Baihaqi, I., dan Bramanti, G. W. \\ Departemen Manajemen Bisnis, Fakultas Bisnis dan Manajemen Teknologi, \\ Institut Teknologi Sepuluh Nopember (ITS) \\ e-mail: senja14@mhs.mb.its.ac.id
}

\begin{abstract}
Abstrak-Supply chain management (SCM) merupakan hal yang penting dikarenakan melibatkan semua elemen yang berpartisipasi. Gangguan atau risiko dalam SCM akan berdampak negatif dalam jangka panjang terhadap kinerja perusahaan. PT Petrokimia Gresik, merupakan perusahaan milik negara yang sadar akan tanggung jawab moral dan sosial terhadap lingkungan dalam aktivitas bisnis mereka yang diwujudkan dalam upaya pengelolaan proses bisnis yang lebih ramah lingkungan. Risiko-risiko yang muncul dalam keseluruhan proses bisnis secara berkelanjutan dapat diminimalisir dengan melakukan identifikasi risiko khususnya yang mempertimbangkan aspek lingkungan di dalam manajemen rantai pasok (green supply chain management). Hasil dari penelitian ini teridentifikasi sebanyak 70 risiko dan 78 agen risiko.
\end{abstract}

Kata Kunci-Green Supply Chain Management, Green Industry, Identifikasi Risiko, Agen Risiko.

\section{PENDAHULUAN}

$S$ YUPPLY Chain Management (SCM) merupakan hal yang sangat penting dikarenakan melibatkan semua elemen yang berpartisipasi serta mengintegrasikan berbagai aktivitas baik produk maupun jasa mulai dari pengadaan bahan baku sampai penyalurannya kepada konsumen, bahkan hingga menjadi barang setelah masa manfaatnya (barang sisa) [1]. Gangguan pada manajemen rantai pasok dapat menyebabkan penurunan kinerja perusahaan baik jangka pendek dan jangka panjang [2].

Tujuan perusahaan untuk memaksimalkan kinerja manajemen rantai pasok, dapat dicapai melalui pengintegrasian praktek pengelolaan lingkungan dalam rangka mencapai manajemen rantai pasok yang lebih ramah lingkungan (green supply chain management) dan mempertahankan keunggulan kompetitif serta meningkatkan keuntungan bisnis [3]. Saat ini baik pemerintah maupun konsumen mulai memiliki kepedulian lebih terhadap kondisi lingkungan mengingat dampak buruk serta risiko yang mungkin ditimbulkan oleh kinerja perusahaan. Maka dari perusahaan perlu melakukan pengelolaan terhadap risiko sehingga tujuan perusahaan dapat tercapai.

Saat ini PT Petrokimia Gresik sedang menggalakkan program untuk mencapai Green Industry, dalam serangkaian proses bisnis yang lebih ramah lingkungan. Selanjutnya dilakukan pengelolaan risiko di dalamnya sekaligus sebagai

Tujuan dari penelitian ini yakni untuk mengidentifikasi risiko dan penyebab risiko. Dengan metode yang digunakan yakni HOR, untuk mengidentifikasi risiko dan agen risiko dan agar kinerja green supply chain management perusahaan dapat menjadi lebih baik.

\section{TINJAUAN PUSTAKA}

\section{A. Supply Chain Management (SCM)}

SCM adalah pengelolaan sepanjang kegiatan rantai pasok dari hulu hingga hilir untuk hasi produk maupun jasa [4]. Pada tingkatan tertinggi, proses terintegrasi dari manajemen rantai pasok dapat dibagi menjadi dua yakni production and inventory control process dan distribution and logistic process.

\section{B. Supply Chain Operations Reference (SCOR)}

SCOR adalah proses bisnis di dalam kegiatan rantai pasok yang didesain oleh Supply Chain Concil [5]. SCOR bertujuan untuk memudahkan perusahaan komunikasi dan interaksi antar pihak mulai dari pemasok hingga pelanggan akhir. Selain itu juga bermanfaat untuk mengembangkan praktik rantai pasok yang baru serta memperbaiki kegiatan rantai pasok yang ada sebelumnya.

\section{Green Supply Chain Management (GSCM)}

Pengintegrasian pemikiran lingkungan ke dalam manajemen rantai pasok adalah konsep GSCM [6]. Konsep ini meningkatkan keseimbangan antara kinerja pemasaran dengan permasalahan lingkungan yang tidak hanya berorientasi pada long-term survival tetapi juga berdampak untuk long-term profitability, dimana image perusahaan serta keuntungan kompetitif di masa datang akan ditingkatkan [7].

\section{Green Supply Chain Risk Management}

Dalam GSCM, risiko dapat terjadi pada kejadian yang tidak dapat dilihat tetapi memberikan dampak pada perpindahan barang berkonsep "green" dan mengganggu aliran barang yang ramah lingkungan, serta produk akhir yang ramah mulai titik produksi hingga konsumsi [8]. Terdapat beberapa faktor risiko di dalam GSCM baik dari sisi eksternal maupun internal perusahaan [9]. Maka dari itu, dibutuhkan manajemen risiko pada kegiatan GSCM sebagai antisipasi maupun mitigasi dari tiap agen risiko yang menimbulkan banyak dampak buruk bagi perusahaan. 


\section{METODOLOGI PENELITIAN}

Pada penelitian ini, tahap penelitian dibagi menjadi dua tahap, yaitu tahap studi lapangan dan tahap identifikasi risiko dan agen risiko.

\section{A. Studi Lapangan}

Pada studi lapangan, akan dilakukan pendataan kondisi eksisting aliran proses bisnis SCM hingga proses bisnis GSCM perusahaan berdasarkan model SCOR melalui metode interview dengan para manajer dan staff ahli masing-masing.

\section{B. Identifikasi Risiko dan Agen Risiko}

Setelah didapatkan proses bisnis GSCM berdasarkan model SCOR, selanjutnya mengidentifikasi risiko dan agen risiko yang diturunkan dari setiap faktor FMEA yakni metode, mesin, manusia, lingkungan, dan persediaan. Metode yang digunakan dalam identifikasi dan agen risiko yakni interview para manajer dan staff ahli terkait.

\section{PEMBAHASAN}

\section{A. Proses Bisnis SCM}

Setelah melakukan interview dengan para manajer dan staff ahli terkait di bidangnya masing-masing, didapatkan beberapa proses bisnis di dalam SCM, yang diturunkan dari setiap model SCOR, seperti hasil di bawah ini:

1. Plan

a. Perencanaan produksi

b. Pengendalian persediaan

2. Source (Proses pengadaan)

3. Make

a. Pelaksanaan dan pengendalian produksi

b. Proses pengemasan

4. Deliver

a. Pemilihan perusahaan jasa pengiriman

b. Penyimpanan produk jadi di Gudang Gresik dan Gudang Open Storage

c. Pengiriman produk kepada konsumen

d. Distribusi produk kepada gudang perwakilan daerah

5. Return
a. Penanganan barang kembali dari konsumen
b. Penanganan barang kembali kepada pemasok

\section{B. Proses Bisnis GSCM}

Setelah proses bisnis SCM didapatkan, selanjutnya diperlukan proses bisnis GSCM yang selanjutnya perlu untuk dilakukan identifikasi risiko dan agen risiko. Berikut Tabel Proses Bisnis GSCM.

Tabel 1.

Proses Bisnis GSCM

\begin{tabular}{cll}
\hline \hline $\begin{array}{c}\text { Proses } \\
\text { Bisnis } \\
\text { (SCOR) }\end{array}$ & SCM & \multicolumn{1}{c}{ GSCM } \\
\hline Plan & $\begin{array}{l}\text { Perencanaan } \\
\text { produksi }\end{array}$ & $\begin{array}{l}\text { Melakukan penjadwalan produksi } \\
\text { sesuai permintaan dan penggunaan alat } \\
\text { pendukung (mesin dan energi) }\end{array}$ \\
& $\begin{array}{l}\text { Pengendalian } \\
\text { persediaan }\end{array}$ & $\begin{array}{l}\text { Melakukan perencanaan dan } \\
\text { pengendalian meminimasi penggunaan }\end{array}$ \\
\hline
\end{tabular}

dan penyimpanan Bahan Baku Berbahaya dan Beracun (B3)

\begin{tabular}{lll} 
Source & Proses & Evaluasi pemilihan dan pengembangan \\
& Pengadaan & $\begin{array}{l}\text { pemasok bahan baku sesuai kriteria } \\
\text { lingkungan (biaya, kualitas, dan etika) }\end{array}$ \\
\cline { 3 - 3 } & & $\begin{array}{l}\text { Proses pengadaan kolaborasi pemikiran } \\
\text { berbasis lingkungan dengan pemasok } \\
\text { bahan baku }\end{array}$ \\
\hline \multirow{2}{*}{ Make } & $\begin{array}{l}\text { Pelaksanaan } \\
\text { pengendalian } \\
\text { produksi }\end{array}$ & $\begin{array}{l}\text { Pelaksanaan produksi dengan mereduksi } \\
\text { penggunaan energi tidak terbarukan dan } \\
\text { sesuai standar lingkungan }\end{array}$ \\
\hline
\end{tabular}

\begin{tabular}{|c|c|c|}
\hline $\begin{array}{l}\text { Proses } \\
\text { Bisnis } \\
\text { (SCOR) }\end{array}$ & $\mathrm{SCM}$ & GSCM \\
\hline & $\begin{array}{l}\text { Proses } \\
\text { pengemasan }\end{array}$ & $\begin{array}{l}\text { Pengawasan kualitas bahan } \\
\text { (material, air, dan lainnya) } \\
\text { dengan standar lingkungan }\end{array}$ \\
\hline \multirow[t]{4}{*}{ Deliver } & $\begin{array}{l}\text { Pemilihan } \\
\text { perusahaan jada } \\
\text { pengiriman }\end{array}$ & $\begin{array}{l}\text { Pemilihan perusahaan jasa pengiriman } \\
\text { yang sesuai standar llingkungan }\end{array}$ \\
\hline & $\begin{array}{l}\text { Penyimpanan } \\
\text { produk jadi di } \\
\text { Gudang Gresik } \\
\text { dan Gudang } \\
\text { Open Storage }\end{array}$ & $\begin{array}{l}\text { Pengawasan dan pengendalian sistem } \\
\text { penyimpanan produk jadi dengan } \\
\text { prioritas sistem First-In-First-Out } \\
\text { (FIFO) }\end{array}$ \\
\hline & $\begin{array}{l}\text { Pengiriman } \\
\text { produk kepada } \\
\text { konsumen }\end{array}$ & $\begin{array}{l}\text { Pengiriman produk jadi kepada } \\
\text { konsumen dengan optimisasi kapasitas } \\
\text { dan jadwal pengiriman untuk } \\
\text { menurunkan konsumsi bahan bakar dan } \\
\text { dampak emisi lingkungan }\end{array}$ \\
\hline & $\begin{array}{l}\text { Distribusi } \\
\text { produk kepada } \\
\text { gudang } \\
\text { perwakilan } \\
\text { daerah }\end{array}$ & $\begin{array}{l}\text { Penggunaan Barcode System dalam } \\
\text { Surat Jalan distribusi produk kepada } \\
\text { Gudang PT Petrokimia Gresik di } \\
\text { beberapa daerah }\end{array}$ \\
\hline \multirow[t]{2}{*}{ Return } & $\begin{array}{l}\text { Penanganan } \\
\text { barang kembali } \\
\text { dari konsumen }\end{array}$ & $\begin{array}{l}\text { Melakukan penjadwalan transportasi } \\
\text { angkutan untuk barag return dari } \\
\text { konsumen (Pusat Pelayanan Pelanggan } \\
\text { Daerah ke PT Petrokimia Gresik) } \\
\text { Melakukan pengelolaan barang return } \\
\text { (Recycle) untuk selanjutnya } \\
\text { didistribusikan kembali }\end{array}$ \\
\hline & $\begin{array}{l}\text { Penanganan } \\
\text { barang kembali } \\
\text { kepada } \\
\text { pemasok }\end{array}$ & $\begin{array}{l}\text { Penanganan barang kembali kepada } \\
\text { pemasok }\end{array}$ \\
\hline
\end{tabular}

\section{Identifikasi Risiko dan Agen Risiko}

Dari aktivitas GSCM di atas maka dilakukan identifikasi risiko dan agen risiko. Kemudian dilakukan penentuan nilai dampak, kemungkinan kejadian, dan nilai korelasi. Risiko yang teridentifikasi sebanyak 70 dan agen risiko teridentifikasi sebanyak 78. Berikut Tabel identifikasi risiko dan agen risiko yang teridentifikasi pada GSCM PT Petrokimia Gresik.

Tabel 2.

Identifikasi Risiko dan Agen Risiko

\begin{tabular}{lrlc}
\hline \hline \multicolumn{1}{c}{ Risiko } & $\begin{array}{c}\text { Kode } \\
\text { Risiko }\end{array}$ & \multicolumn{1}{c}{ Agen Risiko } & $\begin{array}{c}\text { Kode } \\
\text { Agen } \\
\text { Risiko }\end{array}$ \\
\hline $\begin{array}{l}\text { Metode } \\
\text { penjadwalan } \\
\text { produksi belum } \\
\text { diturunkan hingga } \\
\text { jadwal penggunaan } \\
\text { alat pendukung }\end{array}$ & E1 & $\begin{array}{l}\text { Belum ada kebijakan } \\
\text { perusahaan } \\
\text { dibakukan yengenai } \\
\text { penjadwalan penggunaan } \\
\text { mesin dan energi }\end{array}$ & A1 \\
& & $\begin{array}{l}\text { Butuh waktu yang lama } \\
\text { dalam melakukan kajian } \\
\text { dan approval dari Top } \\
\text { Management A2 }\end{array}$ & A2 \\
\hline
\end{tabular}




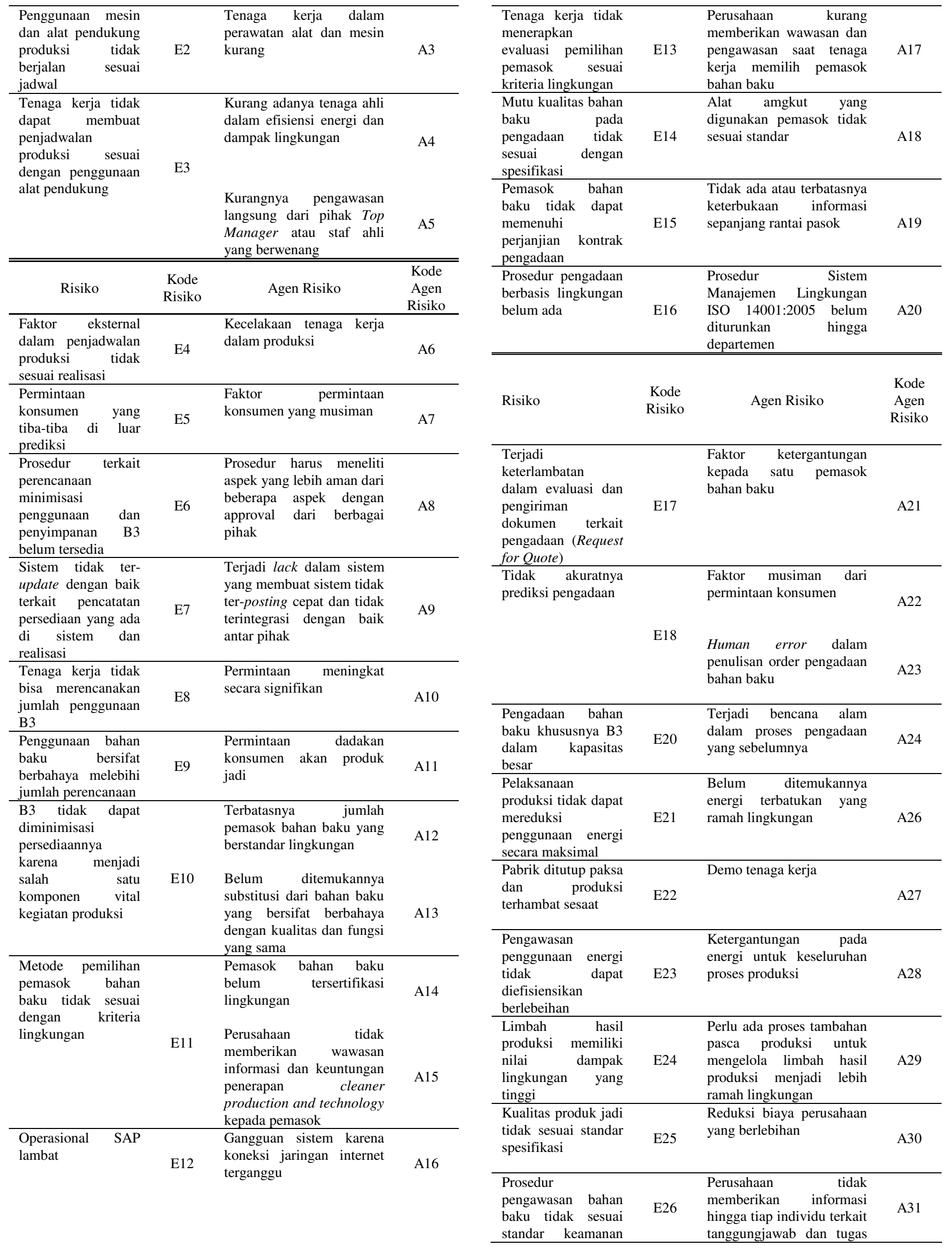




\begin{tabular}{|c|c|c|c|}
\hline lingkungan & & setiap tenaga kerja & \\
\hline $\begin{array}{l}\text { Tidak ada alat ukur } \\
\text { deteksi nilai dampak } \\
\text { lingkungan setiap } \\
\text { bahan baku }\end{array}$ & E27 & 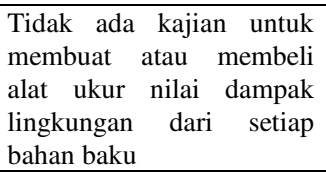 & A 32 \\
\hline $\begin{array}{lr}\text { Kualitas } & \text { bahan baku } \\
\text { yang } & \text { digunakan } \\
\text { belum memenuhi } \\
\text { standar keamanan } \\
\text { lingkungan } \\
\end{array}$ & E28 & $\begin{array}{l}\text { Terbatasnya jumlah } \\
\text { personil laboratorium }\end{array}$ & A33 \\
\hline $\begin{array}{l}\text { Layout pengawasan } \\
\text { kualitas bahan baku } \\
\text { tidak fleksibel }\end{array}$ & E29 & $\begin{array}{l}\text { Tidak ada perbaikan dari } \\
\text { layout bangunan lama } \\
\text { yang menyesuaikan } \\
\text { kebutuhan saat ini }\end{array}$ & A34 \\
\hline $\begin{array}{l}\text { Kekurangan bahan } \\
\text { baku }\end{array}$ & E30 & \begin{tabular}{l}
\multicolumn{2}{l}{ Keterlambatan pemasok } \\
mengirim bahan baku \\
karena mengalami \\
permasalahan internal
\end{tabular} & A 35 \\
\hline
\end{tabular}

\begin{tabular}{|c|c|c|c|}
\hline Risiko & $\begin{array}{l}\text { Kode } \\
\text { Risiko }\end{array}$ & Agen Risiko & $\begin{array}{l}\text { Kode } \\
\text { Agen } \\
\text { Risiko }\end{array}$ \\
\hline $\begin{array}{l}\text { Realisasi } \\
\text { pengemasan produk } \\
\text { belum berstandar } \\
\text { lingkungan }\end{array}$ & E31 & $\begin{array}{l}\text { Belum ada kebijakan } \\
\text { perusahaan mengenai eco- } \\
\text { packaging }\end{array}$ & A36 \\
\hline $\begin{array}{lr}\text { Mesin } & \text { pengemasan } \\
\text { pabrik } & \text { tidak } \\
\text { sepenuhnya } & \text { sesuai } \\
\text { standar lingkungan }\end{array}$ & E32 & $\begin{array}{l}\text { Kurangnya investasi dana } \\
\text { dalam men-substitusi } \\
\text { mesin yang lebih ramah } \\
\text { lingkungan dan efisien }\end{array}$ & A37 \\
\hline $\begin{array}{l}\text { Pengemasan secara } \\
\text { manual-handling }\end{array}$ & E33 & $\begin{array}{l}\text { Kurangnya investasi } \\
\text { perusahaan dalam sistem } \\
\text { pengemasan yang lebih } \\
\text { automasi (eco-packaging) }\end{array}$ & A38 \\
\hline $\begin{array}{lr}\text { Kemasan } & \text { produk } \\
\text { jadi tidak } & \text { dapat } \\
\text { didaur ulang } & \end{array}$ & E34 & $\begin{array}{l}\text { Kemasan produk jadi } \\
\text { belum mengkaji } \\
\text { menggunakan bahan yang } \\
\text { aman terhadap lingkungan }\end{array}$ & A39 \\
\hline $\begin{array}{lr}\text { Produk jadi } & \text { yang } \\
\text { terkemas } & \text { boros } \\
\text { dalam } & \text { ruang } \\
\text { penyimpanan } & \\
\end{array}$ & E35 & $\begin{array}{l}\text { Tidak ada spesifikasi } \\
\text { pengemasan yang lebih } \\
\text { hemat ruang penyimpanan }\end{array}$ & $\mathrm{A} 40$ \\
\hline $\begin{array}{lr}\text { Perusahaan } & \text { jasa } \\
\text { pengiriman } & \text { tidak } \\
\text { sesuai dengan } \\
\text { standar lingkungan }\end{array}$ & E36 & $\begin{array}{l}\text { Belum ada prosedur terkait } \\
\text { pemilihan perusahaan jasa } \\
\text { pengiriman yang sesuai } \\
\text { dengan standar lingkungan }\end{array}$ & A41 \\
\hline $\begin{array}{l}\text { Transportasi } \\
\text { pengiriman masih } \\
\text { tidak sesuai standar } \\
\text { lingkungan }\end{array}$ & E37 & $\begin{array}{l}\text { Terbatasnya perusahaan } \\
\text { jasa yang menyediakan } \\
\text { alat transportasi rendah } \\
\text { emisi }\end{array}$ & $\mathrm{A} 42$ \\
\hline $\begin{array}{l}\text { Tenaga kerja tidak } \\
\text { mempertimbahkan } \\
\text { faktor lingkungan } \\
\text { dalam pemilihan } \\
\text { perusahaan jasa } \\
\text { pengiriman }\end{array}$ & E38 & $\begin{array}{l}\text { Belum ada prosedur terkait } \\
\text { pertimbangan pemilihan } \\
\text { jasa pengiriman yang } \\
\text { sesuai standar lingkungan }\end{array}$ & A43 \\
\hline $\begin{array}{l}\text { Dampak emisi } \\
\text { terhadap lingkungan } \\
\text { tinggi }\end{array}$ & E39 & $\begin{array}{l}\text { Standar emisi lingkungan } \\
\text { tidak bersamaan dengan } \\
\text { standar pemilihan } \\
\text { perusahaan mitra }\end{array}$ & A44 \\
\hline $\begin{array}{l}\text { Keterbatasan jumlah } \\
\text { perusahaan jasa } \\
\text { pengiriman yang } \\
\text { mampu memenuhi } \\
\text { kapasitas } \\
\text { pengiriman dan }\end{array}$ & E40 & $\begin{array}{lr}\text { Perusahaan } & \text { bergantung } \\
\text { kepada pihak } & \text { ketiga } \\
\text { perusahaan } & \text { jasa } \\
\text { pengiriman yang } & \text { mampu } \\
\text { memenuhi } & \text { kapasitas } \\
\text { pengiriman saja } & \end{array}$ & A 45 \\
\hline
\end{tabular}

\begin{tabular}{ll}
\hline sesuai standar \\
lingkungan
\end{tabular}

\begin{tabular}{|c|c|c|c|}
\hline $\begin{array}{l}\text { Prosedur } \\
\text { penyimpanan } \\
\text { produk jadi tidak } \\
\text { sesuai dengan } \\
\text { kaidah FIFO }\end{array}$ & E41 & $\begin{array}{l}\text { Kurangnya pengawasan } \\
\text { dari pihak staf ahli dan } \\
\text { manajer unit }\end{array}$ & A46 \\
\hline $\begin{array}{l}\text { Forklift tidak dapat } \\
\text { meletakkan dan } \\
\text { memindahkan } \\
\text { produk jadi sesuai } \\
\text { dengan kaidah FIFO }\end{array}$ & E42 & $\begin{array}{l}\text { Layout pabrik tidak } \\
\text { fleksibel untuk pergerakan } \\
\text { forklift }\end{array}$ & A47 \\
\hline $\begin{array}{l}\text { Tenaga kerja tidak } \\
\text { mengikuti kaidah } \\
\text { penyimpanan } \\
\text { produk jadi sesuai } \\
\text { kaidah FIFO }\end{array}$ & E43 & $\begin{array}{l}\text { Hukuman dan peringatan } \\
\text { tidak ketat } \\
\text { Layout gudang } \\
\text { penyimpanan produk jadi } \\
\text { tidak fleksibel untuk } \\
\text { loading secara FIFO }\end{array}$ & A48 \\
\hline Risiko & $\begin{array}{l}\text { Kode } \\
\text { Risiko }\end{array}$ & Agen Risiko & $\begin{array}{l}\text { Kode } \\
\text { Agen } \\
\text { Risiko }\end{array}$ \\
\hline $\begin{array}{l}\text { Tata letak fasilitas } \\
\text { dan bongkar muat } \\
\text { tidak sesuai dengan } \\
\text { standar aisle yang } \\
\text { ditetapkan } \\
\end{array}$ & E44 & $\begin{array}{l}\text { Penyimpanan produk jadi } \\
\text { di gudang penyimpanan } \\
\text { melebihi kapasitas gudang }\end{array}$ & A50 \\
\hline $\begin{array}{l}\text { Produk jadi yang } \\
\text { disimpan dalam } \\
\text { Gudang Gresik dan } \\
\text { Open Storage } \\
\text { kualitasnya } \\
\text { menurun atau rusak }\end{array}$ & E45 & $\begin{array}{l}\text { Penempatan produk jadi } \\
\text { yang susah dijangkau oleh } \\
\text { forklift }\end{array}$ & A51 \\
\hline $\begin{array}{l}\text { Prosedur terkait } \\
\text { pengiriman produk } \\
\text { kepada konsumen } \\
\text { belum } \\
\text { memperhatikan } \\
\text { kapasitas } \\
\text { maksimum } \\
\text { kendaraan }\end{array}$ & E46 & $\begin{array}{lr}\text { Prosedur pengiriman } \\
\text { produk jadi ke konsumen } \\
\text { seutuhnya diserahkan } \\
\text { kepada kebutuhan tiap } \\
\text { konsumen } \\
\text { dilaksanakan oleh pihak } \\
\text { transportir langsung tanpa } \\
\text { memperhatikan } \\
\text { keefektivan dari kapasitas } \\
\text { angkut maksimum } \\
\text { kendaraan mang }\end{array}$ & A52 \\
\hline $\begin{array}{lr}\text { Kendaraan muat dan } \\
\text { angkut produk jadi } \\
\text { kepada } r o n s u m e n \\
\text { sudah } & \text { tidak } \\
\text { mumpuni } & \\
\end{array}$ & E47 & $\begin{array}{l}\text { Perusahaan melimpahkan } \\
\text { produk jadi kepada } \\
\text { perusahaan yang memesan } \\
\text { produk }\end{array}$ & A53 \\
\hline 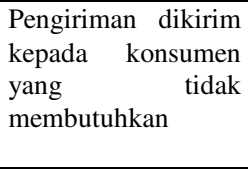 & E48 & $\begin{array}{l}\text { Pihak transportir tidak } \\
\text { memperhatikan tujuan } \\
\text { dengan tidak membaca } \\
\text { detil surat jalan dengan } \\
\text { benar }\end{array}$ & A54 \\
\hline \multirow[t]{2}{*}{$\begin{array}{l}\text { Pengiriman tidak } \\
\text { tepat waktu pada } \\
\text { musim bercocok } \\
\text { tanam }\end{array}$} & \multirow[b]{2}{*}{ E49 } & $\begin{array}{l}\text { Pihak transportir tidak } \\
\text { memiliki kapabilitas cukup }\end{array}$ & A55 \\
\hline & & $\begin{array}{lr}\text { Perusahaan } & \text { hanya } \\
\text { bergantung } & \text { kepada } \\
\text { keputusan konsumen } \\
\text { dalam memilih pihak } \\
\text { transportasi }\end{array}$ & A56 \\
\hline
\end{tabular}




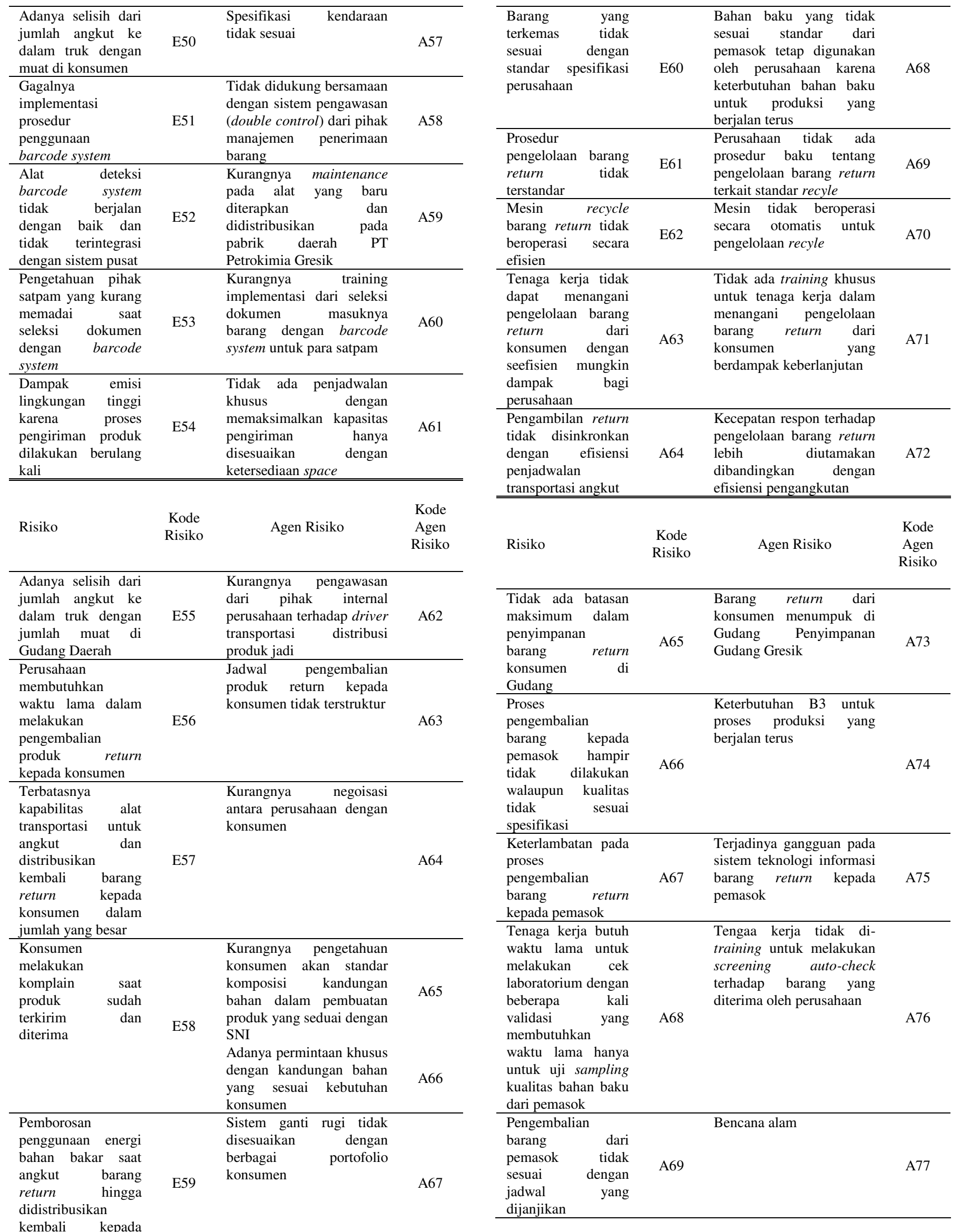




\begin{tabular}{|c|c|c|c|}
\hline $\begin{array}{lr}\text { Jumlah pasokan } \\
\text { bahan baku } & \text { tidak } \\
\text { terpenuhi } & \text { oleh } \\
\text { pemasok } & \end{array}$ & A70 & $\begin{array}{lr}\text { Terbatasnya } & \text { jumlah } \\
\text { pemasok yang } & \text { memenuhi } \\
\text { kriteria } & \end{array}$ & A78 \\
\hline
\end{tabular}

\section{KESIMPULAN DAN SARAN}

\section{A. Kesimpulan}

Berdasarkan hasil identifikasi risiko dan agen risiko dalam penelitian ini didapatkan 70 daftar risiko dan 78 agen risiko yang muncul dari proses bisnis GSCM PT Petrokimia Gresik.

\section{B. Saran}

Saran bagi penelitian selanjutnya yakni perlu dilakukan penilaian guna memitigasi risiko dan agen risiko agar proses bisnis GSCM PT Petrokimia Gresik dapat berjalan lebih baik.

\section{DAFTAR PUSTAKA}

[1] C. Cooper, Douglas, M. Lambert, Martha, and J. D. Pagh, "Supply Chain Management: More Than a New Name for Logistics," Int. J. Logist. Manag., vol. 8, no. 1, pp. 1-14, 1997.
[2] K. B. Hendrick and V. R. Singhal, "An Empirical Analysis of The Effect of Supply Chain Disruptions on Long-run Stock Price Performance and Equity Risk of the Firm," J. Oper. Manag., vol. 14, no. 1, pp. 35-52, 2005.

[3] M. Arif, A. Jusoh, N. A. Seman, M. M. Saman, and N. Zakuan, "The Relationship of Green Supply Chain Management And Green Innovation Concept," in International Conference on Asia Pacific Business Innovation and Technology Management, 2012.

[4] R. Daft, Supply Chain Management. Madison: South Western College Publisher, 2003.

[5] S. C. Council, "Supply Chain Operations Reference Model, 10.0," 2010. [Online]. Available: http://supply-chain.org/scor/10.0. .

[6] S. K. Srivastava, "Green Supply Chain Management: A State of The Art Literature Review," Int. J. Manag. Rev., vol. 9, no. 1, pp. 5380, 2007.

[7] N. Figueiredo and S. F. Mayerle, "Designing Minimum Cost Collection Recycling Networks with Require Throughput," Transp. Res. Part E, vol. 44, no. 3, pp. 731-752, 2008.

[8] M. K. Barua, P. Kumar, and S. K. Mangla, "Risk Analysis in Green Supply Chain Using Fuzzy AHP Approach: A Case Study," Recycl. Resour. Conserv., 2015.

[9] R. Huang, R. Ma, and L. Yao, "The Green Supply Chain Management Risk Analysis," Adv. Mater. Res., vol. 5, pp. 734-739, 2012. 